\title{
A rare case of adult herpes simplex encephalitis complicated with rhabdomyolysis
}

\author{
Qinwei $\mathrm{Yu}^{1 \dagger}$, Chao Han ${ }^{2+}$, Lei Pei ${ }^{3}$, Jinsha Huang ${ }^{1}$, Yan Xu and Tao Wang ${ }^{1 *}$
}

\begin{abstract}
Background: Compelling evidence indicates that status epilepticus is a prevalent cause of rhabdomyolysis. However, cases of rhabdomyolysis induced by a single seizure accompanied by viral encephalitis are rarely reported. Herein, we present a case of adult Herpes Simplex Encephalitis complicated with rhabdomyolysis.
\end{abstract}

Case presentation: A 32-year-old male was patient presented with fever accompanied by episodes of convulsions, myalgia, and oliguria, which exacerbated the delirium. Routine blood examination showed impaired kidney function and elevated myoglobin (Mb) and creatine phosphokinase (CK) levels. MRI scanning revealed a damaged frontotemporal lobe and limbic system. In addition, herpes simplex virus (HSV) pathogen was identified in the cerebrospinal fluid thus indicating HSV infection. Therefore, a diagnosis of rhabdomyolysis triggered by HSV infection accompanied by epilepsy was made. Notably, the patient recovered well after early intervention and treatment.

Conclusion: The case presented here calls for careful analysis of rhabdomyolysis cases with unknown causes, minor seizures, and without status epilepticus. This case also indicates that HSV virus infection might contribute to the rhabdomyolysis.

Keywords: Herpes simplex encephalitis, Rhabdomyolysis, Virus, Seizures

\section{Background}

Rhabdomyolysis is a disease that disrupts the integrity of muscle cell membranes causing unprecedented release of cell contents such as myoglobin (Mb), enzymes like creatine phosphokinase (CK), and toxic substances such as ions into the blood [1]. These factors trigger internal environment disorders, and acute kidney injury or other tissue/organ damage in more serious cases. Rhabdomyolysis is caused by factors including trauma, variation in body temperature, muscle hypoxia, drugs, toxins, electrolyte or metabolic disorders, viral and bacterial

\footnotetext{
* Correspondence: wangtaowh@hust.edu.cn

${ }^{+}$Qinwei Yu and Chao Han are co-first authors.

'Department of Neurology, Union Hospital, Tongji Medical College,

Huazhong University of Science and Technology, 1277 Jiefang Road, Wuhan 430022, Hubei, China

Full list of author information is available at the end of the article
}

infections, as well as the status epilepsy [2]. However, rhabdomyolysis induced by a single seizure is largely unexplored. Notably, Herpes simplex encephalitis (HSE) is a necrotizing encephalitis induced by herpes simplex virus (HSV) infection. Based on its antigenicity, HSV is classified into HSV-1 and HSV-2. Adult HSE is frequently caused by HSV-1 infection in the frontotemporal lobe and limbic system whereas HSV-2 infection induces genital diseases and neonatal encephalitis [3]. Reports indicate that $50 \%$ of patients diagnosed with HSE might develop epilepsy [4]. This study report an unusual case of rhabdomyolysis triggered by a single epilepsy, rather than status epilepticus. The condition stemmed from HSV infection.

(c) The Author(s). 2021 Open Access This article is licensed under a Creative Commons Attribution 4.0 International License, which permits use, sharing, adaptation, distribution and reproduction in any medium or format, as long as you give appropriate credit to the original author(s) and the source, provide a link to the Creative Commons licence, and indicate if changes were made. The images or other third party material in this article are included in the article's Creative Commons licence, unless indicated otherwise in a credit line to the material. If material is not included in the article's Creative Commons licence and your intended use is not permitted by statutory regulation or exceeds the permitted use, you will need to obtain permission directly from the copyright holder. To view a copy of this licence, visit http://creativecommons.org/licenses/by/4.0/ The Creative Commons Public Domain Dedication waiver (http://creativecommons.org/publicdomain/zero/1.0/) applies to the data made available in this article, unless otherwise stated in a credit line to the data. 


\section{Case presentation}

A 32-year-old male patient with a medical history of hepatitis without poisoning presented to our hospital because of untreated mild fever (not exceeding $38.5^{\circ} \mathrm{C}$ ) for 5 days and blood urine. Moreover, the patient developed epilepsy accompanied by unconsciousness. Upon hospitalization, he was depressed. His vital signs including blood pressure, heart rate, and oxygen saturation were normal. Neurological examination revealed a mild stiffness in the neck and gastrocnemius pain. Besides, a positive Babinskin sign was detected, and no other abnormal findings were identified. Routine blood examination showed extremely high $\mathrm{Mb}(12,000 \mathrm{~g} / \mathrm{L}$, normal < $140 \mathrm{~g} / \mathrm{L})$ and CK $(197,159 \mathrm{U} / \mathrm{L}$, normal 38-174 U/L), low GFR (glomerular filtration rate) demonstrated impaired renal function $(26 \mathrm{ml} / \mathrm{min}$, normal $90-120 \mathrm{ml} /$ min). White blood cells, CRP (C-reactive protein), ESR (erythrocyte sedimentation rate), hepatic function were moderately elevated. Other indices including the ANCA/GBM, tumor markers and thyroid function, blood sugar, electrolyte, and sexually transmitted diseases (including human immunodeficiency virus (HIV)) were within normal range. Further, cerebrospinal fluid (CSF) examination revealed elevated protein levels $(0.92 \mathrm{~g} / \mathrm{L}$, normal $0.15-0.45 \mathrm{~g} / \mathrm{L})$ and mildly increased leukocytes $\left(12.9^{*} 10 \sim 6 / \mathrm{L}\right.$, normal $\left.<8 * 10 \sim 6 / \mathrm{L}\right)$, indicating a high possibility of viral encephalitis infection. The left temporal lobe, hippocampus, and insula were swollen and exhibited a high T2 signal as observed on the MRI image (Fig. 1a and b). Considering the MRI findings and his clinical manifestation, this study tested for the presence of HSV pathogen in the CSF. As expected, the HSV-1 gene sequence was detected via DNA sequencing of pathogenic microorganisms. Notably, HSV-2 and other common causes of rhabdomyolysis such as varicella-zoster virus, Epstein-Barr virus, cytomegalovirus, human herpesvirus 6, enterovirus, dengue, Zika, West Nile, H1N1 or scrub typhus infection were not detected via the Metagenome Next Generation Sequencing (mNGS). Besides, based on the sequencing results, other bacteria, fungi, parasites, and mycobacterium were negative. Furthermore, serum CMV, enterovirus, and coxsackievirus were negative (Supplementary material 1 and 2). As a result, herpes simplex encephalitis infection was confirmed. Based on these findings, the patient was eventually diagnosed with rhabdomyolysis, acute renal failure, and epilepsy due to HSV infection. During 3 weeks of hospitalization, the patient was antivirally treated with $300 \mathrm{mg}$ acyclovir at intervals of every $8 \mathrm{~h}$ a day, antiepileptic management with 300 $\mathrm{mg}$ oxcarbazepine, and $500 \mathrm{mg}$ sodium valproate simultaneously administered twice a day. Also, the patient was administered with $10 \mathrm{mg}$ dexamethasone to manage inflammation. Due to the extremely high content of
$\mathrm{Mb}$ and $\mathrm{CK}, 1000 \mathrm{ml}$ saline and a single hemodialysis sustained for $8 \mathrm{~h}$ were used as rehydration therapy (Fig. 1e). A complete remission was achieved after 3 weeks of treatment. After discharge, the patient was placed on continuous orally antiviral (acyclovir, 100 $\mathrm{mg}$, three times a day) and antiepileptic drugs (sodium valproate, $500 \mathrm{mg}$, twice a day) for 4 weeks, after which he returned for a follow-up visit. MRI images taken at follow-up revealed significant improvement of intracranial lesions (Fig. 1c and d) and the viral PCR using the CSF sample was negative for HSV-1 and HSV-2.

\section{Discussion and conclusion}

This study presents a case of HSE with secondary epilepsy, accompanied by rhabdomyolysis and acute renal failure. The initial symptoms included fever and headache, followed by convulsions, notably, without dominant signs of herpes simplex infection such as skin lesion. CSF examination and typical images of MRI confirmed the diagnosis of HSE. Besides, based on symptoms such as myalgia, hematuria, and high blood content of CK and $\mathrm{Mb}$, we confirmed rhabdomyolysis and acute renal failure.

Importantly, rhabdomyolysis induced by HSE, a rarely reported complication was a novel finding of the present case. Despite the prevalent cause being status epilepticus, epilepsy triggered by HSE was ascribed to the occurrence of rhabdomyolysis [5]. Given that the patient was highly muscular, it was likely that a single strong contraction of muscles could rupture the muscle cells [6]. Besides, the virus itself might cause rhabdomyolysis, as in the case of influenza virus infection frequently reported frequently [7]. Other causes including herpes simplex virus, coxsackievirus, and HIV have been reported [8]. In the present case, a broad range of coinfection factors including pathogenic microorganisms known to trigger multisystem dysfunction were excluded. In addition, other underlying metabolic factors as among them, hypoglycemia, hypothyroidism, electrolyte disturbance, hypoxia, and food deficiency were ruled out. Concerning the mechanisms, we hypothesized that HSE infection detected in the present case might have originated from direct viral invasion into the muscle cells, attributed to the presence of other reported viral DNA in the muscle specimen $[8,9]$. Also, the circulating viral toxins might damage the muscle cells [1]. Nonetheless, the specific mechanisms by which HSV induces rhabdomyolysis are underexplored. Therefore, we postulated that the combined effects of epilepsy and virus infection triggered the occurrence of rhabdomyolysis after HSE infection.

Rhabdomyolysis is relatively rare in clinical practice, with varying etiology. Moreover, its typical symptoms 


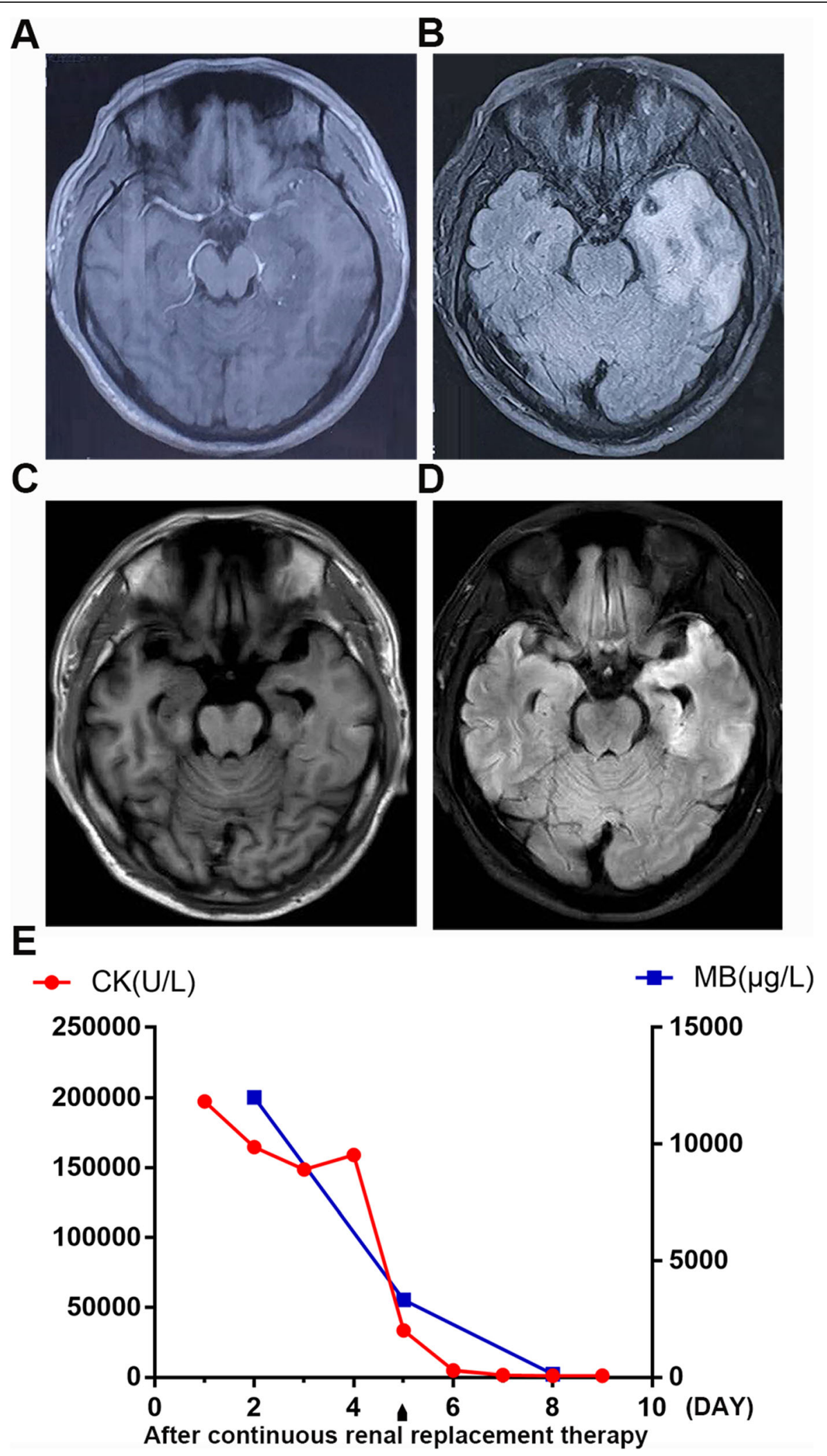

Fig. 1 (See legend on next page.) 
(See figure on previous page.)

Fig. 1 the changes of MRI images and content of MB and CK before and after treatment. $\mathbf{a}$ and $\mathbf{b}$ The left temporal lobe, hippocampus and insula were swollen as seen on the MRI image and high T2 signal was seen in these areas upon hospitalization. $\mathbf{c}$ and $\mathbf{d}$ MRI images taken at follow-up revealed significant improvement of the intracranial lesions. e The trend of $\mathrm{Mb}$ and $\mathrm{CK}$ of the patient before and after treatment of hemodialysis. Mb, myoglobin. CK, creatine phosphokinase

such as myalgia, soy urine, and fatigue are manifested in less than $10 \%$ of all patients [10]. The mortality rate of rhabdomyolysis is estimated at $61.2 \%$ of all clinically ill patients [11]. Herein, we suggest that timely detection and diagnosis, immediate administration of antiviral and rehydration therapies, is critical for a full recovery.

\section{Supplementary Information}

The online version contains supplementary material available at https://doi. org/10.1186/s12879-021-05798-1.

\section{Additional file 1.}

Additional file 2

\section{Abbreviations}

Mb: Myoglobin; CK: Creatine phosphokinase; HSV: Herpes simplex virus: HSE: Herpes simplex encephalitis; GFR: Glomerular filtration rate; CRP: Creactive protein; ESR: Erythrocyte sedimentation rate; ANCA GBM: Antineutrophil cytoplasmic antibody/ Glomerular Basement Membrane; CSF: Cerebrospinal fluid; HIV: Human immunodeficiency virus

\section{Acknowledgements}

We would like to express our thanks to the patient and the technical support from Darui Medical Laboratory Company.

\section{Authors' contributions}

QY and LP collected the patient data and images according to the advice from $\mathrm{CH}$ and TW. QY wrote the original manuscript with support from $\mathrm{CH}$. $\mathrm{JH}$ and $\mathrm{YX}$ analyzed the data. TW was responsible for revising the draft. All authors contributed to the final manuscript and agreed to submit.

\section{Funding}

This work was supported by grants 2017YFC1310200 (to TW) 2016 YFC1306000 (to TW) from the National Key R\&D Program of China; the Fundamental Research Funds for the Central Universities (to $\mathrm{CH}$ ); grants 81974201 (to TW), 81671260 (to TW), grants 81873734 (to YX), and 81301082 (to JSH) from the National Natural Science Foundation of China. The funders had no role in study design, collection, analysis, interpretation of data and in writing the manuscript.

\section{Availability of data and materials}

All data generated or analyzed are included in this published article.

\section{Ethics approval and consent to participate}

Not applicable.

\section{Consent for publication}

Informed written consent for publication was obtained from the patient prior to collecting information. The patient gave written consent for personal or clinical details along with any identifying images to be published in this study.

\section{Competing interests}

No conflict of interest to declare.

\section{Author details}

'Department of Neurology, Union Hospital, Tongji Medical College, Huazhong University of Science and Technology, 1277 Jiefang Road, Wuhan 430022, Hubei, China. ${ }^{2}$ Department of Neurology, Division of Life Sciences and Medicine, the First Affiliated Hospital of USTC, University of Science and Technology of China, Hefei 230001, Anhui, China. ${ }^{3}$ Traditional Chinese Medicine Hospital of Gongan County, 234 Youjiang Road, JingZhou 434300, Hubei, China.

Received: 30 March 2020 Accepted: 12 January 2021

Published online: 23 January 2021

\section{References}

1. Ayala E, Kagawa FT, Wehner JH, Tam J, Upadhyay D. Rhabdomyolysis associated with 2009 influenza A (H1N1). Jama. 2009:302(17):1863-4.

2. Bagley WH, Yang H, Shah KH. Rhabdomyolysis. Intern Emerg Med. 2007;2(3): 210-8.

3. Bradshaw MJ, Venkatesan A. Herpes simplex virus-1 encephalitis in adults: pathophysiology, diagnosis, and management. Neurotherapeutics. 2016; 13(3):493-508.

4. Misra UK, Tan CT, Kalita J. Viral encephalitis and epilepsy. Epilepsia. 2008; 49(Suppl 6):13-8.

5. Singhal PC, Chugh KS, Gulati DR. Myoglobinuria and renal failure after status epilepticus. Neurology. 1978;28(2):200-1.

6. Lin AC, Lin CM, Wang TL, Leu JG. Rhabdomyolysis in 119 students after repetitive exercise. Br J Sports Med. 2005;39(1):e3.

7. Shanmugam S, Seetharaman M. Viral rhabdomyolysis. South Med J. 2008; 101(12):1271-2.

8. Singh U, Scheld WM. Infectious etiologies of rhabdomyolysis: three case reports and review. Clin Infect Dis. 1996;22(4):642-9.

9. Pratt RD, Bradley JS, Loubert C, LaRocco A Jr, McNeal RM, Newbury RO, Sawyer MH. Rhabdomyolysis associated with acute varicella infection. Clin Infect Dis. 1995:20(2):450-3.

10. Khan FY. Rhabdomyolysis: a review of the literature. Neth J Med. 2009;67(9): 272-83.

11. McMahon GM, Zeng $X$, Waikar SS. A risk prediction score for kidney failure or mortality in rhabdomyolysis. JAMA Intern Med. 2013;173(19):1821-8.

\section{Publisher's Note}

Springer Nature remains neutral with regard to jurisdictional claims in published maps and institutional affiliations.

Ready to submit your research? Choose BMC and benefit from:

- fast, convenient online submission

- thorough peer review by experienced researchers in your field

- rapid publication on acceptance

- support for research data, including large and complex data types

- gold Open Access which fosters wider collaboration and increased citations

- maximum visibility for your research: over $100 \mathrm{M}$ website views per year

At $\mathrm{BMC}$, research is always in progress.

Learn more biomedcentral.com/submission 